\title{
Thin-layer acrylamide gel electrophoresis
}

\author{
MANIS NANDI AND GEORGE P. LEWIS \\ From the Divisions of Clinical Pharmacology, Lemuel Shattuck Hospital, Tufts University \\ Medical School, Boston, and the Veterans Administration Hospital, Boston, Massachusetts, USA
}

SYNOPSIS A thin-layer acrylamide gel electrophoresis technique suitable for analysis of serum or urine proteins is described in detail. The method gives sharp differentiation of protein fractions and is particularly suitable for the analysis of biological solutions containing proteins in low concentration.

This paper describes a two-phase acrylamide gel electrophoresis technique based on the disc electrophoresis methods described by Davis (1964), Ornstein (1964), and Williams and Reisfield (1964). It is suitable for analysis of as many as 14 serum protein samples at a time with an electrophoretic running time of three hours. The procedure is more economical of materials and simpler than both vertical slab (Raymond, 1964) and disc acrylamide gel electrophoreses. In addition, because of the thinness of the gel used, staining and subsequent background clearing can be achieved rapidly.

\section{Materials and Methods}

\section{APPARATUS}

1 A water-cooled Laurell type electrophoresis apparatus with accessories for thin-layer agar gel electrophoresis ${ }^{2}$. Accessories consist of (a) a rectangular glass plate of $8 \times 4 \frac{1}{4} \times \frac{1}{16}$ in.,

\footnotetext{
'This research was supported by clinical pharmacology training grant no. HE 5616-05 from the National Heart Institute and in part by contract PH 43-67-1485, National Institute of General Medical Sciences and Clinical Pharmacology Training and Research Program no. 42, Veterans Administration, USA.

2Apparatus with accessories obtainable from Metaloglass Inc., Boston. Mass., USA.
}

Received for publication 16 February 1970. (b) a rectangular plastic slot forming plate of $8 \times 4 \frac{1}{4} \times \frac{1}{8}$ in., and (c) a three-sided plastic frame of $\frac{1}{16}$ in. thickness and $\frac{1}{2}$ in. width which when sandwiched between the glass and plastic plates forms a gel space $7 \times 31 \times \frac{1}{16}$ in.

2 Pasteur pipettes drawn out to fine points.

\section{REAGENTS}

1 Acrylamide (Cyanogum-41 from American Cyanamide Co.), $10 \%$ solution in distilled water. Following filtration this solution can be stored at $4^{\circ} \mathrm{C}$.

2 TEMED-N, N, N ${ }^{1}, \mathbf{N}^{1}$, Tetramethylethylenediamine (Eastman Organic Chemicals).

3 Buffer solutions used included the following:

Running gel ( $p \mathrm{H} \mathrm{8.9):} \mathrm{Tris,} 12 \mathrm{~g}(1 \mathrm{M})$; glycine, $3 \mathrm{~g}(0.4 \mathrm{M})$; TEMED, $0.3 \mathrm{ml}$; and distilled water is added to make $100 \mathrm{ml}$.

Spacer gel ( $p \mathrm{H} \mathrm{6.7):} \mathrm{Tris,} 1.2 \mathrm{~g}(0 \cdot 1 \mathrm{M})$; glycine, $0.3 \mathrm{~g}(0.04 \mathrm{M})$; TEMED, $0.6 \mathrm{ml}$; dissolved in $75 \mathrm{ml}$ of distilled water and adjusted to $p \mathrm{H} 6.7$ with orthophosphoric acid. Final volume is made up to $100 \mathrm{ml}$ with distilled water.

Electrode buffer ( $p \mathrm{H} \mathrm{8.3)}$

Stock solution is made up of Tris, $431 \mathrm{~g}(1.8 \mathrm{M})$; $\mathrm{Na}_{2}$ EDTA, 37g $(0.05 \mathrm{M})$; boric acid, $220 \mathrm{~g}$ $(1.8 \mathrm{M})$; and distilled water is added to make final volume of 2 litres.

The working solution is made up of stock $\stackrel{\mathbb{Q}}{\varrho}$ solution diluted 20 times before use. The buffers $\underset{\gamma}{\sigma}$ are stored at $4^{\circ} \mathrm{C}$.

4 Ammonium persulphate-1\% solution in distilled water.

5 Bromophenol blue crystals. 
Procedure and Results

\section{PREPARATION OF GEL}

A sandwich of the glass plate, plastic frame, and the slot forming plate is made so that the teeth of the slot forming plate lie near the open end of the gel forming space. The three components, held together by bulldog paper clamps, are then supported in a vertical position with the open end uppermost. Running gel, made of $21 \mathrm{ml}$ of $10 \%$ acrylamide solution, $3 \mathrm{ml}$ of buffer, $1.5 \mathrm{ml}$ of $1 \%$ ammon. persulph., and $4.5 \mathrm{ml}$ of distilled water, is stirred vigorously in a small beaker, using a magnetic stirrer for two minutes, and immediately poured into the gel forming space so as to fill it to $0.3 \mathrm{~cm}$ below the line of the slot forming teeth. Distilled water is then layered very gently on top of the gel so as to eliminate meniscus formation. The frame is then left undisturbed for 15 minutes to allow polymerization to take place. The water is removed and the inside is dried with narrow strips of Whatman $3 \mathrm{MM}$ filter paper. Spacer gel, made of $9 \mathrm{ml}$ of $10 \%$ acrylamide solution, $3 \mathrm{ml}$ of buffer, $2.0 \mathrm{ml}$ of $1 \%$ ammon. persulph., and 16.0 $\mathrm{ml}$ of distilled water, is stirred for two minutes and poured on top of the running gel so as to fill the remaining space. Following polymerization $(15-20 \mathrm{~min})$, the sandwich is laid on a flat surface with the slot forming plate uppermost. The slot forming plate is then eased from the frame using a fine spatula.

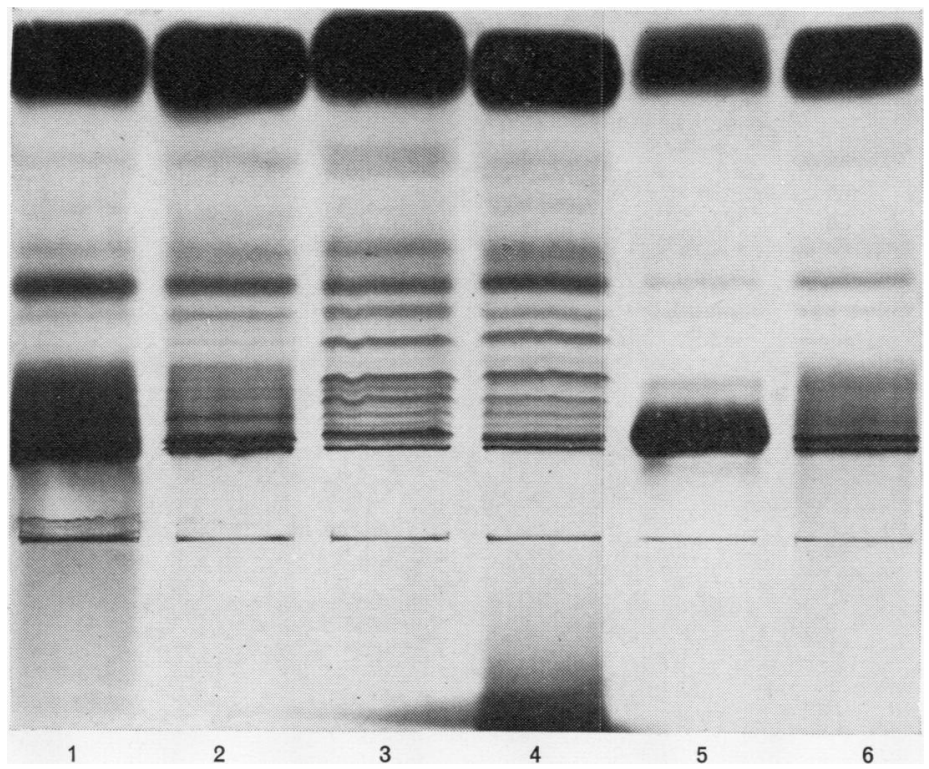

Fig. 1 Serum protein patterns. Sera samples from six medical patients run on acrylamide gel and stained with amido black. Pertinent diagnoses: 1, Laennec's cirrhosis; 2, normal serum; 3, hypogammaglobinaemia; 4 and 5, multiple myelomas; 6, postnecrotic cirrhosis.
ELECTROPHORESIS

The gel on the supporting glass plate withou samples is placed on the cooled platform of the electrophoretic tank and run for 15 minutes allow equilibration to take place between gel an\& electrode buffers. The electric current is turnea off and the samples (to each of which a fer crystals of bromophenol blue have been addef to act as a marker) are placed in the application slots with fine drawn out Pasteur pipettes. \& current of three milliamperes per $\mathrm{cm}$ width applied for three hours (precise time of running depends on the migration of bromophenol blue dye attached to albumin). Circulating tap watef is used for cooling the electrophoresis tank.

\section{STAINING}

Serum proteins

The gel is stained with $1 \%$ amido black in $10 \%$ acetic acid for one hour. Background destaining of the gel is effected by continuous washing (using a magnetic stirrer) in $7 \%$ acetic acid eigh -12 hours (overnight). A permanent record of the protein patterns can be made by direct scannin of each in a densitometer (eg, Chromoscarn Joyce and Loebl Co.) using transmitted light. As an alternative, a high quality black an\& white photograph of the gel (Polaroid MP $\$$ camera and $4 \times 5$ in. type 52 film) can b马 scanned using reflected light. The results obtaine using either of these methods is for all practic purposes identical. The latter procedure has the advantage that a permanent photographic recor 1 is available for future reference.

\section{Haptoglobin phenotype}

The gel, after electrophoresis, is flooded with $5 \%$ (w/v) orthotolidine in $90 \%$ acetic acid for 10 minutes and then washed with 1 vol $\%$ hydroge peroxide. Within two to three minutes haptoglobin phenotype patterns appear which reach a point of maximum clarity within 10 to 15 minutes. Af photographic record taken at this time can be used for quantitating the various fractions.

\section{Results and Discussion}

Figures 1 and 2 show the quality of the pattern obtained using the thin-layer acrylamide gef electrophoresis technique. The patterns ar£ highly reproducible and give more detailed fractionation of serum proteins than is obtainables by use of paper, cellulose acetate, agarose, or starch gel electrophoresis. The improvement i mainly due to the employment of a two-phase system. This allows protein fractions in low concentration to aggregate at the inter-geß boundary (Ornstein, 1964) inducing separatior of protein into fine compacted linear bands. 
Ferrihaemalbumin

Free haemoglobin

Haptoglobin-

haemoglobin

complexes

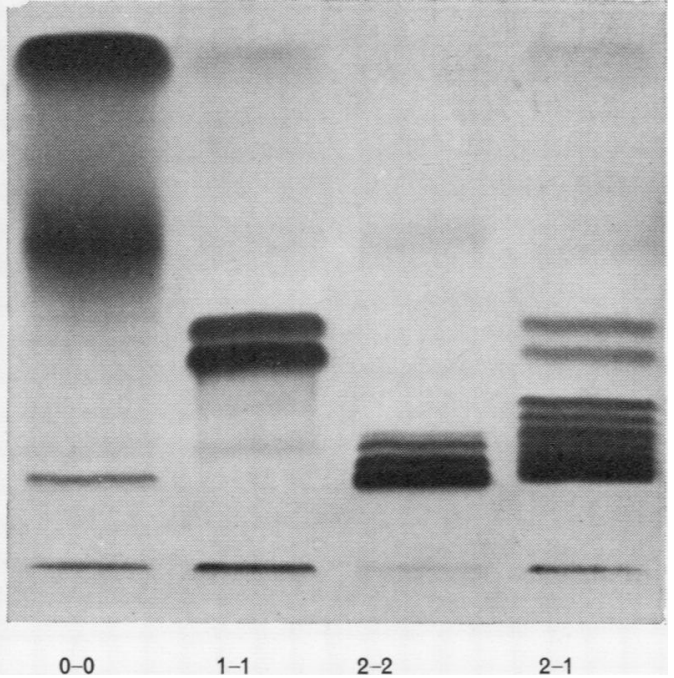

Fig. 2 Serum haptoglobin phenotype patterns. Eight $\mathrm{mg} \mathrm{Hb} \%$ was added to each sample before electrophoresis on acrylamide gel. Phenotypes (left to right) 1-1 (unsaturated), 2-2, and 2-1. The fast moving band in each instance corresponds to the position of ferrihaemalbumin. The intermediate band is free haemoglobin.
This method is very suitable for routine ana- $\frac{\rho}{\overline{5}}$ lysis of sera samples in a clinical laboratory 0 setting and can be used as an alternative method to disc electrophoresis (Davis, 1964) for research $\overline{0}$ purposes (Hawiger, Niewiarowski, Gurewich, $\stackrel{\sim}{\Rightarrow}$ and Thomas, 1970). This technique has been found to be more sensitive than starch gel foro typing haptoglobin phenotypes in the presence $\frac{\bar{D}}{2}$ of profound hypohaptoglobinaemia (Nandi, $\frac{\bar{\rho}}{\vec{\rho}}$ Lewis, Jick, Slone, Shapiro, and Siskind, 1970). $\stackrel{\mathbb{D}}{\circ}$

References

Davis, B. J. (1964). Disc electrophoresis. II. Method and application to human serum proteins. Ann. N.Y. Acad. Sci., 121 ,

Hawiger, J., Niewiarowski, S., Gurewich, V., and Thomas, D. P. Nu (1970). Measurement of fibrinogen and fibrin degradation $\omega$ products in serum by staphylococeal clumping test. $\infty$ J. clin. lab. Med., 75, 93-108.

Nandi, M., Lewis, G. P., Jick, H., Slone, D., Shapiro, S., and N Siskind, V. (1970). Evaluation of haptoglobin phenotype $0-0$ in cirrhotic and non-cirrhotic hospital populations. J. clin. Path., 23, 695-699.

Ornstein, L. (1964). Disc electrophoresis. I. Background and theory. Ann. N.Y. Acad. Sci., 121, 321-49.

Raymond, S. (1964). Acrylamide gel electrophoresis. Ann. N.Y. Acad. Sci., 121, 350-65.

Williams, D. E., and Reisfield, R. A. (1964). Disc electrophoresis in polyacrylamide gels, extension to new conditions of pH and buffer. Ann. N.Y. Acad. Sci., 121, 373-81.

\section{Reports and Bulletins prepared by the Association of Clinical Biochemists}

The following reports and bulletins are published by the Association of Clinical Biochemists. They may be obtained from The $\Rightarrow$ Administrative Office, Association of Clinical Biochemists, 7 Warwick Court, Holborn, London, WC1R 5DP. The prices include 3 postage, but airmail will be charged extra. Overseas readers should remit by British Postal or Money Order. If this is not possible the equivalent of 10s. is the minimum amount that can be accepted.

\section{SCIENTIFIC REPORTS}

3 Automatic Dispensing Pipettes. An assessment of 35 commercial instruments 1967 P. M. G. BROUGHTON, A. H. GOWENLOCK, G. M. WIDDOWSON, and K. A. AHLQUIST 17s (\$2)

\section{An Evaluation of 5 Commercial} Flame Photometers suitable for the Simultaneous Determination of Sodium and Potassium March 1970 P. M. G. BROUGHTON and J. B. DAWSON $17 \mathrm{~s}(\$ 2)$

\section{TECHNICAL BULLETINS}

9 Determination of Urea by AutoAnalyzer November 1966 RUTH M. HASLAM 8s 6d (\$1)

10 Filter Fluorimeters. A comparative list of 14 instruments March 1967 HANNELORE BRAUNSBERG (Re-issued in response to demand. Text still valuable, list now out of date) $8 \mathrm{~s} 6 \mathrm{~d}(\$ 1)$
11 Determination of Serum Albumin by AutoAnalyzer using Bromocresol Green October 1967 B. E. NORTHAM and G. M. WIDDOWson 8s $6 \mathrm{~d}(\$ 1)$

13 An Assessment of the Technicon Type II Sampler Unit March 1968 B. C. GRAY and G. K. MCGOWAN 8s 6d (\$1)

14 Atomic Absorption Spectroscopy. An outline of its principles and a guide to the selection of instruments May 1968 J. B. DAwson and P. M. G. BROUGHTON 8s $6 \mathrm{~d}(\$ 1)$

15 A Guide to Automatic Pipettes (2nd edition) June 1968 P. M. G. BROUGHTON 8s 6d (\$1)

16 A Guide to Automation in Clinical Chemistry May 1969 P. M. G. BROUGHTON 12s 6d (\$1.50)
17 Flame Photometers (2nd edition) 1969 P. WILDING $12 \mathrm{~s} 6 \mathrm{~d}(\$ 1.50)$

18 Control Solutions for Clinical Biochemistry (4th edition) March 1970 P. M. G. BROUGHTON $12 \mathrm{~s} 6 \mathrm{~d}(\$ 1.50)$

19 Spectrophotometers. A comparative list of low-priced instruments readily available in Britain May 1970 c. E. WILDE and P. SEWELL 12s $6 \mathrm{~d}(\$ 1.50)$

20 Quantities and Units in Clinical Biochemistry June 1970 P.M.G. BROUGHTON $12 \mathrm{~s} 6 \mathrm{~d}(\$ 1.50)$ More than 30 copies in units of 10 at $4 \mathrm{~s}$ 